\title{
A Scaling Study by Pair-Wise Comparison Method: Friend Choosing in Adolescents ${ }^{1}$
}

\author{
Esra Eminoğlu Özmercan ${ }^{1}$, Hatice Kumandaş ${ }^{2}$ \\ ${ }^{1}$ Ministry of National Education, İstanbul, Turkey \\ ${ }^{2}$ Artvin Çoruh University, Artvin, Turkey \\ Correspondence: Esra Eminoğlu Özmercan, Ministry of National Education, İstanbul, Turkey
}

Received: March 8, 2016 Accepted: March 16, 2016 Online Published: March 25, 2016

doi:10.11114/jets.v4i6.1494 URL: http://dx.doi.org/10.11114/jets.v4i6.1494

\begin{abstract}
This study aims to identify the perception levels of characteristics considered important to choose friends by adolescents from secondary education and to scale them with pair-wise comparison judgements. In this respect, this study was conducted with 100 10th grade students from a state vocational high school located in Marmara region in Turkey. Data obtained from pairwise comparison was scaled, mean error, chi square and consistency were calculated. The results revealed that the least important factor when choosing a friend is his/her being aggressive while the most recognized factor is his/her being cheerful. Same order was observed for the scale values calculated with V. and III. conditional equation.
\end{abstract}

Keywords: choosing friend, pair-wise comparison judgements scaling, V. conditional equation, III. conditional equation

\section{Introduction}

\subsection{Problem}

Individuals as a communal and social entity, they need to live together with other people, to share and to communicate. Human relationship is the foundations of living in a society together. Therefore, people who can build healthy relationship are accepted and embraced by the society. Socializing process for an individual start just after the birth and does not end until he/she dies (Ergün, 1987). It can be listed that there are various variables affecting individuals' socializing process such as family, school, mass media. Adolescents' relationships with their friends are another factor in that sense.

When literature is examined, it is observed that there are different descriptions regarding friendship. Friendship is described in lexical context as a situation in which individuals show love and understanding to each other. Friendship can also be defined as to determine the qualification of the connections between people and also as to obtain information mutually, to show respect together, to try to help each other when the times are hard and support each other (TDK, 2010). Hartup (1978) states that friendship is a mutual connection which can be highly sensitive from time to time. According to Wright (1984), friendship is a voluntary interactive tie which people are not forced to choose, but they choose anyway. Hays (1988) mentions that friendship is a voluntary cooperation which involves different kinds and levels of togetherness, sincerity, love and helping each other in order to fulfill the social and affective requirements.

People who are friends show commitment and dedication to each other. Their interest generally tends to be same or very identical. Friends spare time for each other, spend time together, share their happiness and sadness. Friendship covers a big responsibility for children's' socializing process such as expressing themselves, sharing their ideas, taking responsibilities etc. In order to be able build healthy relations and have an active social life, children are to start making friends and try to improve them when they are adolescents (Öztürk, 2004).

Adolescents are a compulsory period in which each individual builds his/her identity. Adolescents get effected by their families, school environment and friends while they are re-building their identity (Delikara, 2001). Therefore, it can easily be observed that there are three different types of friendship in this period. These are close relationships, large

\footnotetext{
${ }^{1}$ An earlier version of this paper presented at the III. Congress on Measurement and Evaluation in Education and Psychology that took place at Abant İzzet Baysal University, Bolu, Turkey, on September 19-21, 2012.
} 
groups and individual friendships. Each of these groups has a different importance in an adolescents' life. What makes the biggest difference is the individual friendship. Adolescents expect help from their close friends for any kind of matter. In this period, friendship takes a different role than it does in childhood. Adolescents assign friendship meanings as commitment, loyalty, love and confidence.

Adolescents need to find out who they are, how they are different from their families, what they feel about their environment and what they think about themselves. Adolescents try to accept themselves, find their personalities and balance their autonomy, freedom and responsibility and also try to be accepted by their peers (Nelsen \& Lott 2001). Social circle for adolescents is a communication group in which adolescents find themselves accepted or try to be accepted. Being in a social circle means talking, communication, discussion, studying together, going out can affect the adolescents' attitudes and behaviors. On the other hand, it also plays an important role as it helps diminishing the anxiety, concern, tension and uneasiness. Being in a social circle increases an adolescents' thinking, decision making, enterprising and creativity (Köknel, 1991).

Individuals in their adolescent period mostly make friends according to their will. In this respect, it is important to declare what they care when they choose their friends for their individual development. Benenson \& Benarroch (1998) investigated whether the gender, academic success, physical appearance, popularity, attractiveness and close friends have an effect on 41 students' friendships. 'Friendship Scale' was used in the study as measurement tool. According to the results, boys care physical appearance the most while the girls prefer attractiveness and popularity the most. Guralnick (2005) defends that honesty, being good hearted, sharing the same or identical opinions are the criteria to choose friends. Besides, features such as communication ability, empathy skills, being cool and controlled are considered as very important elements socially and individually to choose friends. A study which was conducted with 204 adolescents showed that social behaviors, personality and characteristics are considered much more important than success and physical appearance in terms of social acceptance. This finding is valid for all adolescents from elementary and second grade schools (Meyers \& Nelson, 1986; cited by İnanç, Bilgin, \& Atıc1, 2004). Adolescents are to show similar features with other members of the group in order to be accepted.

Academic success and sport skills contribute to the social attractiveness. Besides these, physical appearance and being financially wealthy affect the social acceptance. Adolescents care much for personal features as they grow older and less for success and physical appearance. Another feature adolescent consider important is to learn new qualifications and skills appreciated by others to be accepted by the society (Ladd, 2005). Youngsters with social attractiveness are accepted mostly because their personalities, social skills and appearances. These youngsters who have a self-respect and dress according to the criteria of the social circle they belong are usually friendly, happy, cheerful, extrovert, moving, social and ready to participate to the social events (İnanç, Bilgin, \& Atıc1, 2004).

As mentioned in the literature, choosing friends in puberty is crucial. In the studied conducted, the features considered important in this period were examined; yet, the comparison between these features have not studied. For this reason, it is considered necessary and important to determine the features adolescents take care. In this study, it is aimed to identify the perception levels of characteristics considered important to choose friends by adolescents from secondary education and to scale them with pair-wise comparison judgements.

\section{Method}

\subsection{Research Model}

This study is a quantitative research designed to scale pre-determined characteristics for a friend via pair-wise judgements comparison by students.

\subsection{Study Group}

This study was conducted with 100 10th grade students from a state vocational high school located in Marmara region in Turkey in 2010-2011 academic year

\subsection{Data Collection}

A measurement tool concerning choosing friends was developed in order to determine the characteristics student pay attention while making friends. Activity book for 10th grade guidance and counseling prepared by the Republic of Turkey Ministry of National Education was used. Those features were regulated for pair-wise comparison and also viewed by three experts from measurement and evaluation and psychological counseling and guidance fields. The measurement tool was re-designed according to the expert group's opinions.

\subsection{Data Analysis}

Improvement in scaling techniques was first started with psychophysics which is a sub-field of experimental psychology. This discipline focuses on making connections between the perceived and the real sizes of the constructs to be measured 
(Dunn-Runkin, 1982; Crocker \& Algina, 1986). There are two approaches in scaling: 1- Approaches based on the subject reactions and 2-expert group decisions. Expert group decision scaling approach scales the stimulants under a specific dimension based on the expert group opinions. Pair-wise comparison judgement scaling which was developed by Thurstone (1927) was used in this study. Pair-Wise Comparison Judgements Scaling Method was first used to scale attitudes. This method can only be used if the stimulants can be presented in two at a time. This method is frequently used to scale affective features (Turgut \& Baykul, 1993).

In order to analyze the research data, frequency matrixes of students' answers were formed separately for each student. Ratio matrix (P) was also calculated by value for each cell of frequency matrix was divided to total number of students (N). Standardized $\mathrm{Z}$ values for each cell of ratio matrix was also calculated in order to unit normal deviation matrix (Z). These steps were followed till the measurement tool was scaled in full data matrix by III. and V. conditional equations of state of comparative judgement rule. In order to calculate the internal consistency of scale values, the congruence between observed Pjk ratios and scale oriented Pjk values are to be determined. To accomplish this aim, $\mathrm{Z}$ unit normal deviation matrix is produced based on the scale values obtained from analysis of practice data. Theoretical ratio matrix (Z') is calculated based on the $\mathrm{Z}$ unit normal deviation matrix. The consistency between theoretical and observed ratio. In this context, mean error scores of scale values are calculated first. A small mean error score indicates the expert group opinions' to be reliable while a big mean error score indicates the expert group opinions' to be untrusting. The big mean error score may be because the assumptions of the model have not been met, or expert group opinions are not to be relied on or because of both error sources mentioned (Turgut \& Baykul, 1993). In other words, mean error score presents the mean value of consistency between observed values and theoretical values. Chi square test is used to determine whether this consistency is statistically significant. This test is conducted with the formulas presented below. Calculated chi square is compared with the table value identified according to the significancy level regarding degree of freedom. If calculated chi square is smaller than the table value, the scale has the internal consistency. On the other hand, if the calculated chi square has statistically significant, it is decided then that the scale does not have internal consistency. Kendall's coefficient of concordance is used in order to decide if the observer judgements are consistent. Contradictory triple for each observer were examined. Data matrix was produced for each observer for this purpose. These matrixes were designed as if one stimuli were preferred over another, was coded in line as " 1 " and in column as " 0 ". $a_{j}$ and $a_{j}{ }^{2}$ were calculated by adding up the columns of this matrix. Then value of "d" was calculated by the formula $\mathrm{d}=1 / 12$. K.(K-1). (2K-1)-1/2. $\sum \mathrm{a}_{\mathrm{j}}^{2}$. As $\mathrm{K}=9$, coefficient of consistency was calculated with $(\zeta)=1-(24 \mathrm{~d} / \mathrm{K} 3-\mathrm{K})$. Chi square was used to investigate the significance of the result. In conclusion, it was concluded that there were no contradictory triple with $\mathrm{df}=20 ; \mathrm{p}=0,05$.

Along with the description of subjects, give the mended size of the sample and number of individuals meant to be in each condition if separate conditions were used. State whether the achieved sample differed in known ways from the target population. Conclusions and interpretations should not go beyond what the sample would warrant.

\subsubsection{Measures and Covariates}

Include in the Method section information that provides definitions of all primary and secondary outcome measures and covariates, including measures collected but not included in this report. Describe the methods used to collect data (e.g., written questionnaires, interviews, observations) as well as methods used to enhance the quality of the measurements (e.g., the training and reliability of assessors or the use of multiple observations). Provide information on instruments used, including their psychometric and biometric properties and evidence of cultural validity.

\subsubsection{Research Design}

Specify the research design in the Method section. Were subjects placed into conditions that were manipulated, or were they observed naturalistically? If multiple conditions were created, how were participants assigned to conditions, through random assignment or some other selection mechanism? Was the study conducted as a between-subjects or a within-subject design?

\subsubsection{Experimental Manipulations or Interventions}

If interventions or experimental manipulations were used in the study, describe their specific content. Include the details of the interventions or manipulations intended for each study condition, including control groups (if any), and describe how and when interventions (experimental manipulations) were actually administered.

The text size of formula should be similar with normal text size. The formula should be placed in the middle and serial number on the right. For example:

$$
a^{2}+b^{2}=c^{2}
$$




\section{Findings and Comments}

In this section, scaling process conducted with the V. and the III. conditional equations of state were presented respectively.

\subsection{Scaling by $V$. Conditional Equation of State}

Stimulus concerning the top nine features of choosing friends were grouped two at a time. Students were asked to clarify which one they prefer from each category. The judgement frequencies (sj $>$ sk) of each feature was shown in the row score matrix in table 1.

Table 1. Row Scores Matrix for Features of Choosing Friend F $\left[n\left(s_{j}>s_{k}\right]\right.$

\begin{tabular}{llllllllll}
\hline Stimulus & SC & IN & BH & FT & CF & ST & FG & AG & PP \\
\hline SC & & 64 & 37 & 14 & 91 & 44 & 15 & 6 & 33 \\
IN & 36 & & 29 & 18 & 89 & 38 & 20 & 9 & 30 \\
BH & 63 & 71 & & 17 & 88 & 49 & 23 & 10 & 45 \\
FT & 86 & 82 & 83 & & 94 & 89 & 65 & 37 & 79 \\
CF & 9 & 11 & 12 & 6 & & 27 & 19 & 10 & 34 \\
ST & 56 & 62 & 51 & 11 & 73 & & 27 & 9 & 50 \\
FG & 85 & 80 & 77 & 35 & 81 & 73 & & 9 & 55 \\
AG & 94 & 91 & 90 & 63 & 90 & 91 & 91 & & 81 \\
PP & 67 & 70 & 55 & 21 & 66 & 50 & 45 & 19 & \\
\hline Total & 496 & 531 & 434 & 185 & 672 & 461 & 305 & 109 & 407 \\
\hline
\end{tabular}

Each member of $\mathrm{F}$ matrix was divided with $\mathrm{N}(\mathrm{N}=100)$. As a result, P ratio matrix shown in table 2 was produced.

Table 2. Ratio Matrix for Features of Choosing Friend $P\left[n\left(s_{j}>s_{k}\right) / N\right]$

\begin{tabular}{llllllllll}
\hline Stimulus & SC & IN & BH & FT & CF & ST & FG & AG & PP \\
\hline SC & & 0,640 & 0,370 & 0,140 & 0,910 & 0,440 & 0,150 & 0,060 & 0,330 \\
IN & 0,360 & & 0,290 & 0,180 & 0,890 & 0,380 & 0,200 & 0,090 & 0,300 \\
BH & 0,630 & 0,710 & & 0,170 & 0,880 & 0,490 & 0,230 & 0,100 & 0,450 \\
FT & 0,860 & 0,820 & 0,830 & & 0,940 & 0,890 & 0,650 & 0,370 & 0,790 \\
CF & 0,090 & 0,110 & 0,120 & 0,060 & & 0,270 & 0,190 & 0,100 & 0,340 \\
ST & 0,560 & 0,620 & 0,510 & 0,110 & 0,730 & & 0,270 & 0,090 & 0,500 \\
FG & 0,850 & 0,800 & 0,770 & 0,350 & 0,810 & 0,730 & & 0,090 & 0,550 \\
AG & 0,940 & 0,910 & 0,900 & 0,630 & 0,900 & 0,910 & 0,910 & & 0,810 \\
PP & 0,670 & 0,700 & 0,550 & 0,210 & 0,660 & 0,500 & 0,450 & 0,190 \\
\hline Total & 4,960 & 5,310 & 4,340 & 1,850 & 6,720 & 4,610 & 3,050 & 1,090 & 4,070 \\
\hline
\end{tabular}

$\mathrm{Z}$ values equaled to $\mathrm{P}$ matrix elements were calculated. After that step, $\mathrm{Sj}$ values were found by calculating the mean scores for each column. Those values were organized as scale values by making the lowest score equal to zero. Sj ve Sc values were presented in table 3 .

Table 3. Unit Normal Deviation Matrix for Features of Choosing (Z)

\begin{tabular}{llllllllll}
\hline Stimulus & SC & IN & BH & FT & CF & ST & FG & AG & PP \\
\hline SC & & 0,358 & $-0,332$ & $-1,080$ & 1,341 & $-0,151$ & $-1,036$ & $-1,555$ & $-0,440$ \\
IN & $-0,358$ & & $-0,553$ & $-0,915$ & 1,227 & $-0,305$ & $-0,842$ & $-1,341$ & $-0,524$ \\
BH & 0,332 & 0,553 & & $-0,954$ & 1,175 & $-0,025$ & $-0,739$ & $-1,282$ & $-0,126$ \\
FT & 1,080 & 0,915 & 0,954 & & 1,555 & 1,227 & 0,385 & $-0,332$ & 0,806 \\
CF & $-1,341$ & $-1,227$ & $-1,175$ & $-1,555$ & & $-0,613$ & $-0,878$ & $-1,282$ & $-0,412$ \\
ST & 0,151 & 0,305 & 0,025 & $-1,227$ & 0,613 & & $-0,613$ & $-1,341$ & 0,000 \\
FG & 1,036 & 0,842 & 0,739 & $-0,385$ & 0,878 & 0,613 & & $-1,341$ & 0,126 \\
AG & 1,555 & 1,341 & 1,282 & 0,332 & 1,282 & 1,341 & 1,341 & \\
PP & 0,440 & 0,524 & 0,126 & $-0,806$ & 0,412 & 0,000 & $-0,126$ & $-0,878$ & 0,878 \\
\hline Total & 2,895 & 3,613 & 1,065 & $-6,591$ & 8,482 & 2,086 & $-2,507$ & $-9,350$ & 0,308 \\
\hline Column Mean. (Sj) & 0,322 & 0,401 & 0,118 & $-0,732$ & 0,942 & 0,232 & $-0,279$ & $-1,039$ & 0,034 \\
\hline Sc & 1,361 & 1,440 & 1,157 & 0,307 & 1,981 & 1,271 & 0,760 & 0,000 & 1,073 \\
\hline
\end{tabular}

Values presented in the matrix are also shown in numerical axis (Figure 1).

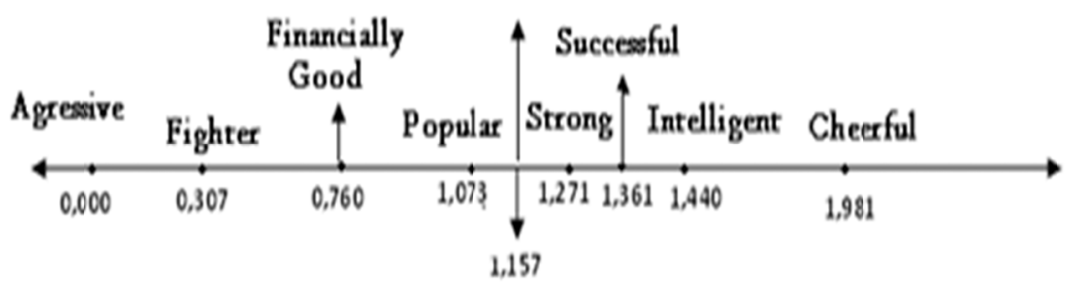

Figure 1. Scale Values calculated by V. Conditional Equation of state 
When the results of the V. conditional equation of state were examined, it was clear that the least important factor when choosing a friend is his/her being aggressive while the most expected factor is his/her being cheerful. Features which are successful, beautiful/handsome and intelligent are not really recognized by students as fundamental features to choose a friend while being fighter and financially wealthy are the mostly used criteria.

\subsection{Internal Consistency of Scale Values}

There were some assumptions to find out the scale values. Obtained scale values were depended on the observers' judgements. It should be checked if the assumptions are true and if the observers are careful with their judgements. In order to check those, internal consistency is examined. To determine the internal consistency, observed $\mathrm{p}_{\mathrm{jk}}$ ratios were used to reveal how much they are congruent with scale values $p_{\mathbf{j k}} z^{\prime}$ unit normal deviation matrix is produced based on the scale values and theoretical matrix is also derived. The congruency between theoretical ratio and observed ratio is examined. To do so, the formula used:

$$
\mathrm{OH}=\frac{\sum_{j>k}\left|p_{j k}-p_{j k}\right|}{K(K-1)}
$$

$\mathrm{OH}=$ Mean error (Mean score of the difference between the observed ratio and theoretical ratio)

$\mathrm{pjk}=$ Ratio obtained from observed frequency

$\mathrm{p}^{\prime} \mathrm{jk}=$ Theoretical Ratio

$\mathrm{K}=$ Stimuli number

A small mean error score obtained from this equation indicates scale values being reliable while a high mean error score obtained from this equation indicates observers' judgements are not reliable because the assumptions are not met or there are error sources not identified in the model. If the difference is significant, "assumptions may not work", "observers were not careful while making observations." And "the observed variable was not uni-dimensional or presented a normal distribution". Mean error score mentioned provides the consistency between observed value and empirical value; in other words, it provides a consistency value. Yet, it does not tell anything for its being significant. Chi square is used for this reason. Theoretical unit normal deviation matrix, theoretical ratio matrix and error score matrix were produced. Certain value for error matrix was used and mean error scores were found out. These values are as presented in table 4.

Table 4. Error Matrix for Features of Choosing Friends

\begin{tabular}{cccccccccc}
\hline Stimulus & SC & IN & BH & FT & CF & ST & FG & AG & PP \\
\hline SC & & 0,108 & 0,049 & 0,006 & 0,177 & 0,024 & 0,124 & 0,027 & 0,057 \\
IN & 0,108 & & 0,099 & 0,052 & 0,184 & 0,053 & 0,048 & 0,015 & 0,057 \\
BH & 0,049 & 0,099 & & 0,027 & 0,085 & 0,055 & 0,116 & 0,024 & 0,016 \\
FT & 0,006 & 0,052 & 0,027 & & 0,013 & 0,058 & 0,025 & 0,010 & 0,012 \\
CF & 0,177 & 0,184 & 0,085 & 0,013 & & 0,031 & 0,079 & 0,076 & 0,158 \\
ST & 0,024 & 0,053 & 0,055 & 0,058 & 0,031 & & 0,035 & 0,012 & 0,078 \\
FG & 0,124 & 0,048 & 0,116 & 0,025 & 0,079 & 0,035 & & 0,134 & 0,073 \\
AG & 0,027 & 0,015 & 0,024 & 0,010 & 0,076 & 0,012 & 0,134 & 0,048 \\
PP & 0,057 & 0,057 & 0,016 & 0,012 & 0,158 & 0,078 & 0,073 & 0,048 \\
\hline Total & 0,573 & 0,615 & 0,471 & 0,202 & 0,804 & 0,346 & 0,633 & 0,345 & 0,499 \\
\hline OH & 0,027 & & & & & & & \\
\hline
\end{tabular}

Mean error provides a value of consistency between observed values and empirical values. To decide whether the value is statistically significant, chi square is examined. To calculate the chi square, the $\mathrm{q}=$ arcsine $\sqrt{p}$ transformation from observed values matrix was done to produce transformed ratio matrix. Based on this transformed matrix, theoretical ratio matrix was produced. Then the differences between these matrixes were calculated.

The square of transformed observed and theoretical ratio differences matrix was produced by calculating the squares of those difference. It was shown in table 5. 
Table 5. Transformed Observed and Theoretical Ratio Differences Square

\begin{tabular}{|c|c|c|c|c|c|c|c|c|c|}
\hline Stimulus & $\mathrm{SC}$ & IN & $\mathrm{BH}$ & FT & $\mathrm{CF}$ & ST & FG & $\mathrm{AG}$ & PP \\
\hline \multicolumn{10}{|l|}{$\mathrm{SC}$} \\
\hline IN & 39,785 & & & & & & & & \\
\hline $\mathrm{BH}$ & 8,404 & 35,732 & & & & & & & \\
\hline FT & 0,236 & 16,832 & 4,136 & & & & & & \\
\hline $\mathrm{CF}$ & 187,135 & 181,748 & 44,221 & 2,753 & & & & & \\
\hline ST & 1,937 & 9,433 & 10,006 & 22,936 & 4,258 & & & & \\
\hline FG & 77,236 & 11,015 & 54,099 & 2,295 & 40,664 & 4,887 & & & \\
\hline $\mathrm{AG}$ & 8,754 & 2,482 & 4,612 & 0,323 & 91,475 & 1,348 & 115,745 & & \\
\hline PP & 11,557 & 11,989 & 0,896 & 0,662 & 108,681 & 20,300 & 17,952 & 13,953 & \\
\hline Total & 335,044 & 269,231 & 117,970 & 28,969 & 245,079 & 26,535 & 133,696 & 13,953 & 0,000 \\
\hline $\mathrm{OH}$ & 1170,48 & & & & & & & & \\
\hline Chi square & 142,57 & & & & & & & & \\
\hline
\end{tabular}

Calculated chi square value was statistically found significant for $\mathrm{sd}=28$ and 0,05 level $(\mathrm{p}<41,34)$. According to this result, data scaled did not meet the assumptions of V. conditional equation of state or the assumptions of pairwise comparison judgement or both. Guilford (1954) proposes to use the III. conditional equation of state for this situations. Standard deviations of distinctive judgements were used in III. conditional equation of state. Standard deviations of distinctive judgements can be predicted from $\mathrm{Z}$ matrix.

\subsection{Scaling by III. Conditional Equation of State}

Steps followed in V. conditional equation of state were similarly followed for III. conditional equation of state until Z unit normal standard deviation matrix was produced.

The total squares of unit normal deviation (Z) matrix and standard deviation of students' distinctive judgements and variances were calculated. This process is presented in appendix 1 . After the variances were found out, the total variances matrix was produced by totaling columns with columns and lines with lines and the square of this matrix was also calculated. This matrix was presented in appendix 2. The matrix of squares of variances total was multiplied with unit normal deviation matrix and the mean scores were calculated; $S_{j}$ values were found out. The minimum value was equated to zero and the rest was designed according to that. Re-designed scale values $\left(\mathrm{S}_{\mathrm{c}}\right)$ were given in table 6 .

Table 6. Scale Values calculated by III. Conditional Equation of State

\begin{tabular}{cccccccccc}
\hline Stimulus & SC & IN & BH & FT & CF & ST & FG & AG & PP \\
\hline SC & 0,000 & 0,239 & $-0,184$ & $-1,228$ & 2,825 & $-0,112$ & $-0,592$ & $-3,316$ & $-0,549$ \\
IN & $-0,239$ & 0,000 & $-0,412$ & $-1,135$ & 2,655 & $-0,273$ & $-0,637$ & $-2,936$ & $-0,704$ \\
BH & 0,184 & 0,412 & 0,000 & $-1,130$ & 2,506 & $-0,020$ & $-0,488$ & $-2,766$ & $-0,162$ \\
FT & 1,228 & 1,135 & 1,130 & 0,000 & 3,657 & 1,572 & 0,459 & $-0,788$ & 1,313 \\
CF & $-2,825$ & $-2,655$ & $-2,506$ & $-3,657$ & 0,000 & $-1,341$ & $-1,876$ & $-3,799$ & $-0,993$ \\
ST & 0,112 & 0,273 & 0,020 & $-1,572$ & 1,341 & 0,000 & $-0,505$ & $-2,968$ & 0,000 \\
FG & 0,592 & 0,637 & 0,488 & $-0,459$ & 1,876 & 0,505 & 0,000 & $-2,899$ & 0,163 \\
AG & 3,316 & 2,936 & 2,766 & 0,788 & 3,799 & 2,968 & 2,899 & 0,000 & 2,134 \\
PP & 0,549 & 0,704 & 0,162 & $-1,313$ & 0,993 & 0,000 & $-0,163$ & $-2,134$ & 0,000 \\
\hline Total & 2,917 & 3,681 & 1,464 & $-9,705$ & 19,652 & 3,299 & $-0,901$ & $-21,607$ & 1,201 \\
\hline Sj & 0,324 & 0,409 & 0,163 & $-1,078$ & 2,184 & 0,367 & $-0,100$ & $-2,401$ & 0,133 \\
\hline Sc & 2,725 & 2,810 & 2,564 & 1,323 & 4,585 & 2,768 & 2,301 & 0,000 & 2,534 \\
\hline
\end{tabular}

Scale values calculated by III. conditional equation of state presented in the matrix are also shown in numerical axis as below.

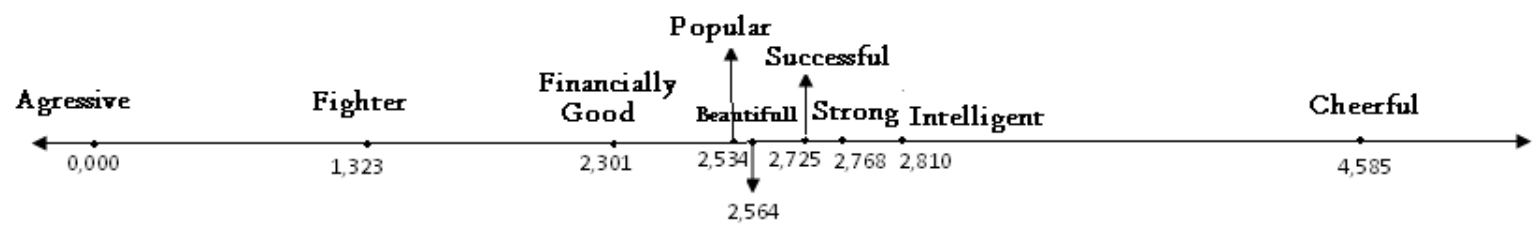

Figure 2. Scale Values calculated by III. Conditional Equation of state

Scale values calculated by III. and V. Conditional Equations of state were comparatively shown. 
Table 7. Scale Values Calculated by III. and V. Conditional Equation of State

\begin{tabular}{lcccc}
\hline & \multicolumn{2}{c}{ III. Conditional Equation } & \multicolumn{2}{c}{ V. Conditional Equation } \\
\hline & Scale Values & Stimulus Order & Scale Values & Stimulus Order \\
SC - Successful & 2,725 & 6 & 1,361 & 7 \\
IN - Intelligent & 2,810 & 8 & 1,440 & 8 \\
BH - Beautiful/Handsome & 2,564 & 5 & 1,157 & 5 \\
FT - Fighter & 1,323 & 2 & 0,307 & 2 \\
CF - Cheerful & 4,585 & 9 & 1,981 & 9 \\
ST - Strong & 2,768 & 7 & 1,271 & 6 \\
FG - Financially Good & 2,301 & 3 & 0,760 & 3 \\
AG - Aggressive & 0,000 & 1 & 0,000 & 1 \\
PP - Popular & 2,534 & 4 & 1,073 & 4 \\
\hline
\end{tabular}

When the table 7 is examined, it can be mentioned that scale values calculated by both equations show identical orders.

\subsection{Internal Consistency and Value Congruence}

Internal consistency of scale values was examined in order to check whether the students were careful with their judgements.

3.4.1 Consistency Value in Scaling

$$
\begin{aligned}
& C_{2}^{100}=100 ! / 2 ! *(100-2) ! \\
& C_{2}^{100}=4950 \\
& C_{2}^{9}=36 \\
& \mathrm{U}=\frac{2 \tau}{C_{2}^{100} \cdot C_{2}^{9}}-1 \\
& \tau=\sum f_{j k}^{2}-N \sum f_{j k}+C_{2}^{100} \cdot C_{2}^{9} \\
& \tau=118942 \\
& \mathrm{U}=0,33 \\
& \mathrm{sd}=(\mathrm{K}) \frac{N(N-1)}{(N-2)^{2}}=37 \\
& \mathrm{X}^{2}=\frac{4}{N-2}\left(\tau-\frac{1}{2}\left[{ }_{2}\right] \cdot\left[{ }_{2}\right]\left(\frac{N-3}{N-2}\right)\right.
\end{aligned}
$$

It was calculated as $\mathrm{X} 2=1255,15$; in this scope, calculated degree of freedom ( $\mathrm{sd}=37$ ) was found to be as 43,77 from the chi square table for $\mathrm{CI}=0,95$.

Calculated chi square value is higher than the table value. In conclusion, it can be stated with $95 \%$ confidence interval that experts did not show consistency regarding scaling those nine features. To be more clear, internal consistency was not ensured. The reason for this situation was thought to be derived from data's showing identical features.

\section{Discussion and Conclusion}

In this study, data obtained from pair-wise comparison judgement method was scaled with V. and III. conditional equations of state. Mean error, chi square and consistency values were calculated. According to the results of the scaling, the least important factor when choosing a friend is his/her being aggressive while the most desired feature is his/her being cheerful. Features which are successful, beautiful/handsome and intelligent are not really recognized by students as fundamental features to choose a friend while being fighter and financially wealthy are the mostly used criteria. 
According to the study by La Fontana \& Cillessen (1999), students in their childhood and early adolescent periods consider older students popular if they are physically attractive while they consider younger students popular if they are academically successful enough (cited by Oral, 2007). The results of this study does not cooperate with La Fontana and Cillessen's findings.

Cleary, Ray, Lobello, \& Zachar (2002) investigated the peer perception in elementary school and its effect on friendship. Results suggested that students demand friends who are easy-going, not aggressive, socially skilled, trustworthy and friends they can do some activities with. (cited by Oral, 2007).

Arısoy (1983) studied youngsters' friend preferences on a sample of 240 high school students. It was determined that students prefer friends who are academically successful and popular. Gender was not mentioned as a factor to make friends by $98 \%$ of the students. Students with low socio-economic background tend to prefer people with less friends. Girls prefer to be friends with people who have their own authentic ideas and opinions while boys prefer to be friends with people whom they share the same or at least identical World view. Except from gender and socioeconomic level, second grade high school students prefer popular students as their friends. Students who are 15-17 years old do not prefer people who criticizes them as their friend. (cited by Oral, 2007).

\section{References}

Benenson, J. F., \& Benarroch, D. (1998). Gender differences in responses to friends hypothetical greater success. Journal of Early Adolescence, 18(2), 192- 208. http://dx.doi.org/10.1177/0272431698018002004

Cleary, D. J., Ray, G. E., Lobello, S. G., \& Zachar, P. (2002). Children's perceptions of close peer relationships: Quality, congruence, and meta-perceptions. Child Study Journal, 32(3), 179-191.

Crocker, L., \& Algina, J. (1986). Introduction to classical \& modern test theory. Florida: Holt, Rinehart and Winston Inc.

Delikara, İ. (2001, March). Ergenlerde akran ilişkileri ile suç kabul edilen davranişlar arasindaki ilişkinin incelenmesi. Paper presented at the Symposium of 1. Ulusal Çocuk ve Suç: Nedenler ve Önleme Çalışmaları, Ankara.

Dunn-Runkin, P. (1983). Scaling methods. Newjersey: Lawrence Erlbaum Associates Publishers.

Ergün, D. (1987). Sosyoloji ve eğitim. Ankara: V Yayınları.

Guralnick, M. J. (2005). Strutting young adolescent's peer relation. Encyclopedia on early childhood development. Montreal, Quebec: Centre of Excellence For Early Child Development.

Hartup, W. W. (1978). Children and their friends. In H. McGurk (Eds.), Childhood social development (pp. 127-137). London: Methuen.

Hays, R. B. (1988). Friendship. In S. W. Duck (Eds.), Handbook of personal relationships: Theory, research, and interventions (pp.391-408). New York: Wiley.

İnanç B. Y., Bilgin, M., \& Atıcı, M. K. (2004). Gelisim psikolojisi. Çocuk ergen gelisimi. Adana: Nobel Kitabevi.

Köknel, Ö. (1991). Gençlik çağında kız-erkek arkadaşlı̆̆ı. Aile yazıları 3. Ankara: T.C. Başbakanlık Aile Araştırma Kurumu Başkanlığı Yayınları.

Ladd, G. W. (2005). Children's peer relations and social competence. New Haven, CT, US: Yale University Press.

Nelsen, J., \& Lott, L. (2001). Ergen gençler için pozitif disiplin (çeviri: Bilge Öztürk), İstanbul: Beyaz Yayınları.

Oral, V. (2007). İlköğretim 5. Sinıf öğrencilerinin arkadaşlarına ilişkin düşüncelerinin sosyometrik statü ve akademik başarı açısından incelenmesi. (Unpublished master's thesis).University of Çukurova, Adana.

Öztürk, O. (2004). Ruh sağll̆̆ ve bozuklukları. Ankara: Nobel Yayıncılık.

TDK, (2010). Türkçe Sözlük. Ankara: Türk Dil kurumu Yayınları.

Thurstone, L. L. (1927). A law of comparative judgment. Psychological Review, 34, 273-286. http://dx.doi.org/10.1037/h0070288

Turgut M. F., \& Baykul, Y. (1993). Ölçekleme teknikleri: Ankara: ÖSYM Yayınları.

Wright, P. H. (1984). Self-referent motivation and the intrinsic quality of friendship. Journal of Social and Personal Relationships, 1, 115-130. http://dx.doi.org/10.1177/0265407584011007 


\section{Appendix A}

Table 8. Finding the Standart Deviation Steps

\begin{tabular}{|c|c|c|c|c|c|c|c|c|c|}
\hline Stimulus & $\mathrm{SC}$ & IN & $\mathrm{BH}$ & FT & $\mathrm{CF}$ & ST & FG & $\mathrm{AG}$ & PP \\
\hline $\mathrm{SC}$ & & 0,128 & 0,110 & 1,167 & 1,798 & 0,023 & 1,074 & 2,417 & 0,194 \\
\hline IN & 0,128 & & 0,306 & 0,838 & 1,504 & 0,093 & 0,708 & 1,798 & 0,275 \\
\hline $\mathrm{BH}$ & 0,110 & 0,306 & & 0,910 & 1,381 & 0,001 & 0,546 & 1,642 & 0,016 \\
\hline FT & 1,167 & 0,838 & 0,910 & & 2,417 & 1,504 & 0,148 & 0,110 & 0,650 \\
\hline $\mathrm{CF}$ & 1,798 & 1,504 & 1,381 & 2,417 & & 0,376 & 0,771 & 1,642 & 0,170 \\
\hline ST & 0,023 & 0,093 & 0,001 & 1,504 & 0,376 & & 0,376 & 1,798 & 0,000 \\
\hline FG & 1,074 & 0,708 & 0,546 & 0,148 & 0,771 & 0,376 & & 1,798 & 0,016 \\
\hline $\mathrm{AG}$ & 2,417 & 1,798 & 1,642 & 0,110 & 1,642 & 1,798 & 1,798 & & 0,771 \\
\hline PP & 0,194 & 0,275 & 0,016 & 0,650 & 0,170 & 0,000 & 0,016 & 0,771 & \\
\hline Total Zj & 2,895 & 3,613 & 1,065 & $-6,591$ & 8,482 & 2,086 & $-2,507$ & $-9,350$ & 0,308 \\
\hline Total $\mathrm{Zj}^{2}$ & 6,911 & 5,651 & 4,912 & 7,746 & 10,059 & 4,170 & 5,437 & 11,976 & 2,091 \\
\hline $\mathrm{k}^{*} \mathrm{Z \textrm {j } ^ { 2 }}$ & 62,200 & 50,861 & 44,209 & 69,714 & 90,528 & 37,528 & 48,929 & 107,782 & 18,821 \\
\hline Total zj2 & 8,381 & 13,053 & 1,134 & 43,442 & 71,940 & 4,350 & 6,286 & 87,420 & 0,095 \\
\hline vj & 0,856 & 0,709 & 0,772 & 0,538 & 0,365 & 0,673 & 0,762 & 0,362 & 0,510 \\
\hline $\mathrm{k}^{*} \mathrm{vj}$ & 7,705 & 6,380 & 6,950 & 4,842 & 3,285 & 6,059 & 6,862 & 3,258 & 4,588 \\
\hline $1 / \mathrm{k}^{*} \mathrm{Vj}$ & 0,130 & 0,157 & 0,144 & 0,207 & 0,304 & 0,165 & 0,146 & 0,307 & 0,218 \\
\hline $\mathrm{k}^{*} \mathrm{c}=2 \mathrm{k} / \sum \mathrm{k}^{*} \mathrm{c}$ & 10,130 & 10,130 & 10,130 & 10,130 & 10,130 & 10,130 & 10,130 & 10,130 & 10,130 \\
\hline Standart Deviation & 0,315 & 0,588 & 0,458 & 1,092 & 2,083 & 0,672 & 0,476 & 2,109 & 1,208 \\
\hline Variance & 0,099 & 0,346 & 0,209 & 1,192 & 4,340 & 0,451 & 0,227 & 4,449 & 1,458 \\
\hline
\end{tabular}

\section{Appendix B}

Table 9. Square Root Matrix of Total Variances

\begin{tabular}{|c|c|c|c|c|c|c|c|c|c|c|}
\hline Stimulus & & $\mathrm{SC}$ & IN & $\mathrm{BH}$ & FT & $\mathrm{CF}$ & ST & $\mathrm{FG}$ & $\mathrm{AG}$ & PP \\
\hline & Variance & 0,099 & 0,3455 & 0,2093 & 1,19228 & 4,3395 & 0,4513 & 0,2267 & 4,44936 & 1,4583 \\
\hline $\mathrm{SC}$ & 0,099 & 0,198 & 0,445 & 0,308 & 1,291 & 4,439 & 0,550 & 0,326 & 4,548 & 1,557 \\
\hline IN & 0,346 & 0,445 & 0,691 & 0,555 & 1,538 & 4,685 & 0,797 & 0,572 & 4,795 & 1,804 \\
\hline $\mathrm{BH}$ & 0,209 & 0,308 & 0,555 & 0,419 & 1,402 & 4,549 & 0,661 & 0,436 & 4,659 & 1,668 \\
\hline FT & 1,192 & 1,291 & 1,538 & 1,402 & 2,385 & 5,532 & 1,644 & 1,419 & 5,642 & 2,651 \\
\hline $\mathrm{CF}$ & 4,340 & 4,439 & 4,685 & 4,549 & 5,532 & 8,679 & 4,791 & 4,566 & 8,789 & 5,798 \\
\hline ST & 0,451 & 0,550 & 0,797 & 0,661 & 1,644 & 4,791 & 0,903 & 0,678 & 4,901 & 1,910 \\
\hline $\mathrm{FG}$ & 0,227 & 0,326 & 0,572 & 0,436 & 1,419 & 4,566 & 0,678 & 0,453 & 4,676 & 1,685 \\
\hline $\mathrm{AG}$ & 4,449 & 4,548 & 4,795 & 4,659 & 5,642 & 8,789 & 4,901 & 4,676 & 8,899 & 5,908 \\
\hline PP & 1,458 & 1,557 & 1,804 & 1,668 & 2,651 & 5,798 & 1,910 & 1,685 & 5,908 & 2,917 \\
\hline
\end{tabular}

\section{$(\mathrm{cc}) \mathrm{EY}$}

This work is licensed under a Creative Commons Attribution 3.0 License. 